\title{
Childhood Central Nervous System Choriocarcinoma
}

National Cancer Institute

\section{Source}

National Cancer Institute. Childhood Central Nervous System Choriocarcinoma. NCI

Thesaurus. Code C6206.

A choriocarcinoma that arises from the central nervous system and occurs during childhood. 